\title{
Coral reef fishes exploit flow refuges in high-flow habitats
}

\author{
J. L. Johansen ${ }^{1, *}$, D. R. Bellwood ${ }^{1}$, C. J. Fulton ${ }^{2}$ \\ ${ }^{1}$ Australian Research Council Centre of Excellence for Coral Reef Studies, and School of Marine and Tropical Biology, \\ James Cook University, Townsville, Queensland 4811, Australia \\ ${ }^{2}$ School of Botany and Zoology, Australian National University, Canberra, Australian Capital Territory 0200, Australia
}

\begin{abstract}
Behaviour can offset the limitations of the morphology and physiology of a species to profoundly influence patterns of resource use. In fishes, flow refuging is a behavioural mechanism that may facilitate the occupation of turbulent, high-flow habitats by reducing extreme environmental demands on their swimming capabilities. Using a novel combination of experimental and field techniques, we examined the refuging patterns of coral reef fishes to demonstrate the potential energetic advantages of flow refuging on coral reefs. Field evaluations of 3 common reef flat species (Halichoeres margaritaceus, Pomacentrus chrysurus and Chrysiptera brownriggi) revealed clear speciesspecific refuge selectively towards substratum holes and coral heads, with all species using these 2 refuge types in a manner that provided significant shelter from ambient flow. Indeed, at experimental flow speeds similar to those in the field (10 to $\left.90 \mathrm{~cm} \mathrm{~s}^{-1}\right)$, measurements taken in and around replicas of these refuges identified flow reductions of 60 to $100 \%$ depending on ambient flow speed, type and size of the refuge. In addition, the degree of refuging displayed by these reef fishes appeared to be strongly linked with swimming ability, with smaller individuals and slower-swimming species refuging more frequently than individuals with stronger swimming abilities (i.e. refuging frequency in $P$. chrysurus $>$ C. brownriggi $>H$. margaritaceus). Ultimately, it appears that refuging is not just a predator-avoidance mechanism, but also enhances the ability of coral reef fishes to sustain themselves in high-flow environments, which may underpin their occupation of otherwise inhospitable wave-swept habitats.
\end{abstract}

KEY WORDS: Fish $\cdot$ Swimming $\cdot$ Microhabitat use $\cdot$ Shelter $\cdot$ Current $\cdot$ Energetics $\cdot$ Flow avoidance Wave energy Resale or republication not permitted without written consent of the publisher

\section{INTRODUCTION}

An important aim for reef fish ecologists is to explain differences in habitat utilisation patterns among the multitude of reef-associated species. Although it is clear that coral reef fishes use a variety of microhabitats, the underlying mechanisms shaping differences in habitat use are still the subject of intensive research (reviewed by Williams 1991, Sale 2002). Generally, dispersal, settlement, competition and predation are thought to be the primary pre- and post-recruitment determinants of habitat use in reef fishes (Sale 2002). However, the ability of each species to cope with the biophysical characteristics of the local environment must also set overall limits to the range of potential habitats that can be occupied. For example, fishes in high-flow habitats can either swim continuously against ambient currents or periodically flow refuge, requiring either a strong swimming ability or well- developed refuging behaviour and appropriate flow refuges. While several studies have demonstrated that high-flow reef habitats support an abundance of fast-swimming fishes (Bellwood \& Wainwright 2001, Fulton et al. 2001, Fulton \& Bellwood 2005), there are indications that some slowerswimming taxa may be exploiting flow refuges to occupy high energy habitats (Bellwood \& Wainwright 2001, Fulton et al. 2001, Johansen et al. 2007). While many fishes use refuges on coral reefs, flow refuging in reef fishes remains a point of contention, with little empirical analysis of this behaviour and a prior focus on refuging as a predator-avoidance mechanism (e.g. Hixon \& Beets 1993, Beukers \& Jones 1998, Sale 2002, 
Lehtiniemi 2005). Using a functional approach, we examined the potential for flow refuging and swimming performance to directly influence patterns of microhabitat use in coral reef fishes.

Flow refuging behaviour can provide significant reductions in the flow experienced by fishes. Recent experimental studies have found that fishes often place themselves behind structures when exposed to high flows (Gerstner \& Webb 1998, Webb 1998, Asaeda et al. 2005), which can significantly reduce physiological swimming demands and directly assist fishes in using high-flow habitats (Liao et al. 2003, Johansen et al. 2007). Energetic benefits to be gained from flow refuging appear to be dependent on the particular behaviour at the individual level, rather than the swimming ability of the species, as individuals can rapidly adjust activity patterns according to ambient flow conditions (Liao et al. 2003, Asaeda et al. 2005). Thus, slow-swimming fishes with well-developed refuging behaviour may be able to use high-flow habitats more efficiently than stronger swimming species with limited refuging behaviour (Johansen et al. 2007). Ultimately, this can lead to a potential expansion of the range of habitats and locations that can be colonised by a species, exceeding predictions based solely on morphology or swimming speed performance.

Here we quantified refuging patterns in 3 species of coral reef fishes to determine if interactions between fish swimming ability and flow refuging may directly contribute to patterns of habitat use in wave-swept habitats. We used a combination of field and laboratory-based measures to address 3 questions: (1) Do reef fishes differ in their degree of refuging and selection of specific refuge types? (2) What degree of flow reduction is provided by the most commonly used refuge types? (3) Are patterns of refuging related to fish size and the dimensions of refuges? We discuss the extent to which these patterns of refuging are reflected in the relative swimming abilities of species based on previous analyses (Fulton 2007).

\section{MATERIALS AND METHODS}

Study sites and species. All field observations were conducted on the wave-exposed coral reef flat between South and Palfrey Islands in the Lizard Island Group, northern Great Barrier Reef, Australia $\left(14^{\circ} 40^{\prime} \mathrm{S}, 145^{\circ} 28^{\prime} \mathrm{E}\right)$. The reef flat was selected for 2 reasons: firstly, it is the shallowest and most waveswept habitat on the reef, with average flows often exceeding $40 \mathrm{~cm} \mathrm{~s}^{-1}$ (Fulton \& Bellwood 2005); secondly, recent studies have suggested that flow refuging is a common phenomenon in these high-flow habitats (Bellwood \& Wainwright 2001, Fulton et al. 2001,
Fulton \& Bellwood 2002a, Johansen et al. 2007). Refuging behaviours in 3 fish species were examined at each of 2 sites (adjacent to each island named above): Pomacentrus chrysurus Cuvier 1839, Halichoeres margaritaceus (Valenciennes 1839) and Chrysiptera brownriggi (Bennet 1828). These species were chosen because they are abundant on the reef flat and display widely different mean pectoral-swimming speeds $\left(U_{\mathrm{pc}}\right)$ : P. chrysurus, $26.7 \mathrm{~cm} \mathrm{~s}^{-1}$; H. margaritaceus, $48.0 \mathrm{~cm} \mathrm{~s}^{-1}$; and C. brownriggi, $35.2 \mathrm{~cm} \mathrm{~s}^{-1}$ (Fulton 2007).

Fish refuging behaviour. Fish refuging behaviour was observed by SCUBA divers using an instantaneous focal monitoring technique following Fulton et al. (2001). Specifically, divers swam in a non-overlapping path across the reef flat while recording data from each individual fish immediately as they were encountered. Species, total length (TL, to the nearest $\mathrm{cm}$ ), distance from the substratum (to the nearest $5 \mathrm{~cm}$ ), and the type of refuge used at the time of first observation were noted for each individual. Great care was taken to minimise observer and predator-related effects by maintaining a minimum distance of $5 \mathrm{~m}$ (usually 10 to $12 \mathrm{~m}$ ) between observer and subject, and observations were made only when no likely predators where visibly present. Whenever fishes were observed to behave adversely to the divers, or if predators were visible, the observation was aborted and excluded from the analyses. This method provided a rapid means of recording refuging behaviour based on independent observations of numerous individual fish. All fish included in this study displayed adult coloration, with an average $\mathrm{TL}$ of $5.6 \pm 0.1 \mathrm{~cm}($ mean $\pm \mathrm{SE}, \mathrm{n}=154)$ for Pomacentrus chrysurus, $7.7 \pm 0.1 \mathrm{~cm}(\mathrm{n}=114)$ for Halichoeres margaritaceus, and $6.3 \pm 0.2 \mathrm{~cm}(\mathrm{n}=71)$ for Chrysiptera brownriggi. Refuging was defined as the prolonged ( $>2 \mathrm{~s}$ ) residence of a fish with more than half its body depth within the enclosure of a refuge (e.g. a substratum hole) or positioned closely (within $5 \mathrm{~cm}$ ) downstream of a substratum structure (e.g. a coral head). In total, 339 individuals of the 3 study species were observed over $9 \mathrm{~d}$ of observation.

Refuge physical characteristics. The study sites examined had similar low-relief topographies with no marked changes in level in the carbonate rock platform, which consisted mainly of pock-marked coral rock, rubble and very few live coral colonies (hard or soft). In total, 171 hard-bottom refuges used by observed individuals were measured for width, length and depth/height using tape measures to the nearest $0.5 \mathrm{~cm}$. Based on the observed refuging patterns, the substratum holes and coral heads were identified as the most commonly used refuges (substratum hole, $\mathrm{n}=$ 60 ; coral head, $\mathrm{n}=58$; other refuge types, $\mathrm{n}=53$ ). Therefore, substratum refuges were divided into 3 distinct refuge types: holes in the substratum, single coral 
heads, and others (i.e. any other hard-substratum structure that was observed to be used by fishes as a refuge, e.g. a sharp drop in substratum level, indentations in the vertical wall of a drop in substratum level, or shelters between proximate substratum protrusions). In each of the 2 study sites, the substratum was surveyed for refuge availability using haphazardly placed $10 \times 3 \mathrm{~m}$ benthic transects. All potential refuges within transects were categorised into the 3 refuge types and measured as described above. Six transects were conducted in each site, with a total of 674 substratum refuges measured. Finally, to assist in experimental measures of flow within refuges (see below), 3 casts of average sized substratum holes (length $10.5[ \pm 1.2] \times$ width $10.5[ \pm 1.2] \times$ depth $9.7[ \pm 0.6] \mathrm{cm}$, mean $\pm \mathrm{SE}, \mathrm{n}=60$ ) and 4 casts of average sized dead coral heads $(14.4[ \pm 1.0] \times 14.4[ \pm 0.9] \times 14.6[ \pm 0.6] \mathrm{cm}$, $\mathrm{n}=58$ ) used as refuges were taken in the field using oil-based modelling clay and plaster.

Refuge flow characteristics. Flow profiles were quantified for the 2 most commonly used substratum refuge types (holes and coral heads) using artificial refuges placed in an experimental flow tank. In particular, replicas of a substratum hole and a coral head refuge were created from the casts made in the field to closely match the actual refuges used by the study species. These replica refuges were placed in a 1941 recirculating flow tank of a design following Vogel \& LaBarbera (1978), and exposed to a range of flow speeds comparable to those found in the field (i.e. 10 to $90 \mathrm{~cm} \mathrm{~s}^{-1}$, Fulton \& Bellwood 2005). However, to minimise solid-blocking effects (i.e. increased flow speeds around obstacles in an enclosed flow chamber), the coral head refuge size was kept at $<10 \%$ of the cross-sectional area of the flow chamber (Bell \& Terhune 1970). With a flow chamber of $55.0 \times 23.0 \times$ $24.0 \mathrm{~cm}$ (length: width: height) the refuge model was scaled down from $14.4 \times 14.4 \times 14.6 \mathrm{~cm}$ to $7.4 \times 7.4 \times$ $7.5 \mathrm{~cm}$, which constitutes $51 \%$ of the average crosssectional diameter of coral heads used as refuges in the field. The dimensions of the replica substratum refuge hole were $10.5 \times 10.5 \times 9.7 \mathrm{~cm}$, and it had a clear acrylic window incorporated into one side and a $1.0 \times 1.0 \mathrm{~cm}$ grid drawn on the back wall of the flow tank or refuge hole to allow for visual analysis of particles moving around the refuge. Flow reduction was then measured around the 2 refuge types across a range of ambient flow speeds (between 10 and $90 \mathrm{~cm}$ $\mathrm{s}^{-1}$ at intervals of approximately $7 \mathrm{~cm} \mathrm{~s}^{-1}$ ) using digital video tracking of neutrally buoyant particles. The movement of at least 5 particles relative to the background grid were analysed at each flow speed inside and outside of the refuges. A minimum of 110 individual measures of flow were conducted for each refuge type.
Flow within the substratum hole and the coral head contained several vortices and circular flow patterns (i.e. turbulence). Therefore, to provide a simple measure of flow speed within the refuges, the speed of each recorded particle was analysed regardless of its specific direction of movement. This provided a conservative estimate of flow within the refuge, as stable points may exist within vortices. Because fishes in the field were defined as refuging only when they were within $5 \mathrm{~cm}$ downstream of the coral heads, particle speed was only analysed in the area directly behind the coral head to a distance of $5 \mathrm{~cm}+$ the average TL $(\sim 7 \mathrm{~cm})$ of the fish. Video recordings were set up with a narrow depth of field so that only those particles directly behind the coral head refuge would be in focus and subsequently included in analyses. Given the smaller coral head refuge used in the flow tank, this analysis represents a conservative estimate of reductions in ambient flow. To provide ground-truthing of relative reductions in flow, field measures of flow speed were collected on the reef flat between South and Palfrey Islands. Ambient flow speed in the water column was measured by timing passive particles as they moved in an approximately linear trajectory between 2 recognisable landmarks on the substratum. This process was repeated for passive particles passing through a substratum hole or around a coral head refuge, using landmarks approximately $10 \mathrm{~cm}$ before and after the refuge. Only those observations where particles completed a full run through the refuge in a roughly linear fashion were included in analyses. In total, 6 flow speed recordings were made for each of the 9 holes, and 9 coral head refuges were examined, and a total of 9 ambient flow measures were taken in the water column approximately $35 \mathrm{~cm}$ above the substratum. All observations were completed under similar tidal and wave conditions.

Statistical analysis. To identify possible site effects, the observed number of refuging versus non-refuging individuals, refuge types selected by each species and the relative availability of each refuge type in the substratum were compared between sites using a series of chi-squared $k$-sample tests. Where no significant differences were detected, field observations were pooled across sites and presented as an overall mean and standard error for each variable.

The observed number of refuging versus non-refuging individuals was compared among species using a chi-squared $k$-sample test. Substratum refuge availability, species specific refuge use and refuge selectivity were graphically displayed following the selectivity index of Chesson (1983). This method has the advantage of providing a selectivity index that will yield a value between -1 and 1 irrespective of resource densities in the environment, is unaffected by the rela- 
tive abundance of the different resource types, and thus permits comparisons of unequal sample sizes. This selectivity index was calculated as: Selectivity $(E)=(m \alpha-1) /[(m-2) \alpha+1]$ where $m=$ the number of refuge types and $\alpha=\left(r_{i} / n_{i}\right) /\left(\sum r_{j} / n_{j}\right)$ with $r_{i}=$ the proportional use of refuge type $i$, and $\mathrm{n}_{i}=$ the proportional availability of refuge type $i$ (Chesson 1983). Furthermore, significant differences between substratum refuge availability and the selective refuge use of each species were analysed using a series of chi-squared 2sample tests, and corrected for type I errors using Bonferroni adjustments. Differences in flow speed inside and outside of the substratum refuges, both experimentally and in the field, were compared using paired $t$-tests for dependent samples. Sized-related changes in refuging patterns within species were examined using a series of non-linear logit regressions performed on the binary data of refuging/non-refuging by different sized fishes. For non-refuging individuals, differences in water column use among species were examined using a 1-way analysis of variance (ANOVA). Finally, the sizes of refuges used by each species were compared to refuge-size availability using $t$-tests for independent samples. All results were analysed using STATISTICA v. 6.1 or SigmaPlot v. 8.0, and probability values less than 0.05 were accepted as significant.

\section{RESULTS}

Pomacentrus chrysurus, Halichoeres margaritaceus and Chrysiptera brownriggi all used substratum refuges on the reef flat and exhibited no significant site effects in this refuging behaviour $\left(P\right.$. chrysurus, $\chi^{2}=$ $0.50, \mathrm{p}=0.48 ;$ H. margaritaceus, $\chi^{2}<0.01, \mathrm{p}=0.98$; C. brownriggi, $\left.\chi^{2}<0.01, \mathrm{p}=0.94\right)$. Refuging patterns were markedly different among the 3 species $\left(\chi^{2}=\right.$ $70.20, \mathrm{p}<0.01$ ) with $P$. chrysurus refuging $76.0 \pm 2.6 \%$ (mean $\pm \mathrm{SE}, \mathrm{n}_{\text {ind }}=154$ ) of the time, while $H$. margaritaceus and $C$. brownriggi were refuging only $28.0 \pm$ $0.1 \%(\mathrm{n}=114)$ and $32.4 \pm 0.4 \%(\mathrm{n}=71)$ of the time, respectively.

Substratum refuge types displayed no significant difference in availability between sites (holes, $\chi^{2}=0.89$, $\mathrm{p}=0.35$; coral heads, $\chi^{2}=0.72, \mathrm{p}=0.40$; other refuges, $\left.\chi^{2}=0.00, p=0.95\right)$. Indeed, substratum refuges were available in approximately equal proportions within sites with $30.4 \pm 1.6 \%$ holes (mean $\pm \mathrm{SE}, \mathrm{n}=205$ ), $36.1 \pm 1.6 \%$ coral heads $(n=243)$ and $33.5 \pm 2.6 \%$ other refuge types ( $n=226$; Fig. 1 ), with the other refuge type consisting mainly of abrupt drops in substratum level and shelters between proximate coral heads.

While refuge selectivity did not differ among sites (Pomacentrus chrysurus, $\chi^{2}=2.67, \mathrm{p}=0.26$; Halichoeres margaritaceus, $\chi^{2}=3.85, \mathrm{p}=0.15$; Chrysiptera

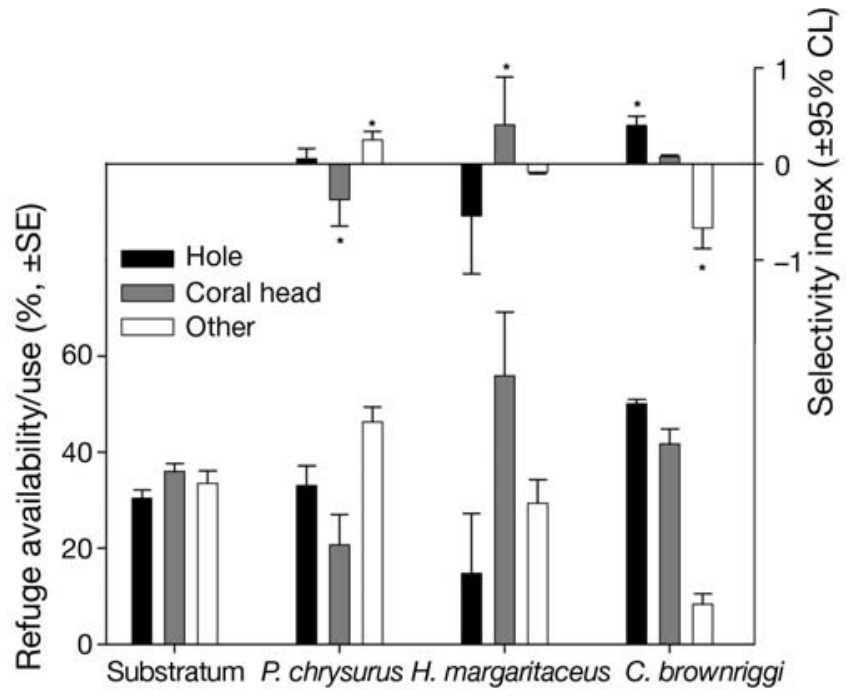

Fig 1. Pomacentrus chrysurus, Halichoeres margaritaceus and Chrysiptera brownriggi. Refuge selectivity. Lower section shows substratum refuge availability and the refuge utilisation patterns of each species across 3 different refuge types. Top section displays selectivity of each species towards each refuge type. The selectivity index ranges from -1 to +1 and represents strong negative to strong positive preference, respectively. 0 represents no preference. CL: confidence limit. ${ }^{*} \mathrm{p}<0.05$

brownriggi, $\chi^{2}=4.17, \mathrm{p}=0.12$ ), all 3 study species displayed varied positive and negative selection towards particular substratum refuge types (Fig. 1). Specifically, $P$. chrysurus displayed a strong negative selectivity for coral heads $\left(\mathrm{n}_{\text {samples }}=2, \chi^{2}=10.23, \mathrm{p}<0.01\right)$ and a strong positive selection for other refuge types $(\mathrm{n}=2$, $\left.\chi^{2}=7.29, \mathrm{p}<0.01\right)$. Conversely, H. margaritaceus exhibited a positive selection for coral heads $\left(\mathrm{n}=2, \chi^{2}=\right.$ 5.79, p < 0.05), while $C$. brownriggi exhibited a positive selection for substratum holes $\left(\mathrm{n}=2, \chi^{2}=8.39, \mathrm{p}<0.01\right)$ and a strong negative selection for other refuge types (n $=2, \chi^{2}=6.69, \mathrm{p}<0.01$; Fig. 1).

Experimental flow velocities measured behind the coral head refuge and within the substratum hole were significantly slower than ambient flows (coral head refuge, $\mathrm{n}=80, t=9.49, \mathrm{p}<0.01$; substratum hole refuge, $\mathrm{n}_{\text {measures }}=80, t=10.38, \mathrm{p}<0.01$; Fig. 2). For example, at an ambient flow of $60 \mathrm{~cm} \mathrm{~s}^{-1}$, the flow behind the coral head was $23.0 \pm 1.5 \mathrm{~cm} \mathrm{~s}^{-1}$ and $12.0 \pm$ $1.6 \mathrm{~cm} \mathrm{~s}^{-1}$ inside the hole (mean $\pm 95 \%$ confidence limit, CL; Fig. 2), constituting a $62 \%$ and a $80 \%$ reduction in flow, respectively. For flow velocities between 10 and $90 \mathrm{~cm} \mathrm{~s}^{-1}$, the flows behind the coral head were always reduced by 60 to $66 \%$, while the larger substratum hole refuge reduced ambient flows by 75 to $100 \%$ (Fig. 2). Under field conditions, an ambient flow speed of $8.85 \pm 0.60 \mathrm{~cm} \mathrm{~s}^{-1}$ produced average flow speeds of $2.70 \pm 0.21 \mathrm{~cm} \mathrm{~s}^{-1}$ behind coral heads and $1.84 \pm$ $0.33 \mathrm{~cm} \mathrm{~s}^{-1}$ in substratum holes, representing average 


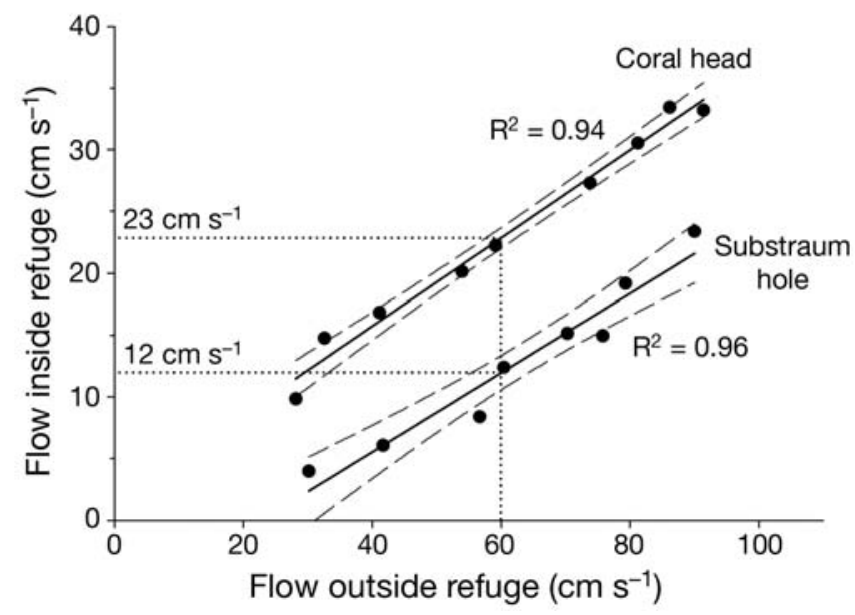

Fig 2. Flow measurements outside and inside of the substratum hole and coral head refuge taken in a recirculating flow chamber. Outside flow is calibrated with neutral density particles ( $\mathrm{n} \geq 5$ per speed), and the inner flow is based on the mean of $\geq 5$ measures of entrained particles passing in the vicinity (see 'Materials and methods') of the refuges. Regression lines and $95 \%$ confidence limits (dashed lines) are shown

flow reductions of $69.5 \%$ and $79.2 \%$, respectively (coral head refuge, $\mathrm{n}=18, t=6.87, \mathrm{p}<0.01$; substratum hole refuge, $\mathrm{n}=18, t=6.48, \mathrm{p}<0.01$ ).

Some species displayed a shift in refuging behaviour with increased body size (Fig. 3, Table 1). With increasing size, Pomacentrus chrysurus and Halichoeres margaritaceus displayed less frequent refuging behaviour (Table 1). In P. chrysurus, the proportion of individuals refuging fell from $100 \%$ to $46.2 \pm 34.5 \%$ with a change in size from $2-3 \mathrm{~cm}$ to $8-9 \mathrm{~cm}$ TL (means $\pm \mathrm{SE}, \mathrm{n}_{\text {ind }}=154$ ). In contrast, $H$. margaritaceus displayed $60.0 \pm 8.3 \%$ refuging at 4 to $5 \mathrm{~cm}$ TL and 9.1 $\pm 6.3 \%$ refuging at 10 to $11 \mathrm{~cm} \mathrm{TL}(\mathrm{n}=114)$. Conversely, refuging behaviour in Chrysiptera brownriggi remained almost stable with size, having a mean of $32.4 \pm 0.4 \%$ across the observed range of sizes $(n=71)$.

When refuging, the sizes of the refuges occupied by each of the study species appeared to be selectively chosen (Table 2). In particular, the average size of coral head refuges used by Halichoeres margaritaceus in the field were significantly smaller than the average coral heads available in the substratum $(t=2.06, \mathrm{n}=$ 253, p < 0.05). Similarly, the substratum holes occupied by Chrysiptera brownriggi were significantly larger than those generally available in the substratum $(t=-2.51, \mathrm{n}=217, \mathrm{p}<0.05)$. When not refuging, the mean height in the water column differed among species $(F=15.65, \mathrm{n}=168, \mathrm{p}<0.01)$, with Pomacentrus chrysurus averaging a distance of $9.0 \pm 1.0 \mathrm{~cm}$ from the substratum (mean $\pm \mathrm{SE}, \mathrm{n}=38$ ), compared to $8.3 \pm 0.6 \mathrm{~cm}$ in $H$. margaritaceus $(\mathrm{n}=82)$ and $17.2 \pm$ $2.2 \mathrm{~cm}$ in C. brownriggi $(\mathrm{n}=48)$.

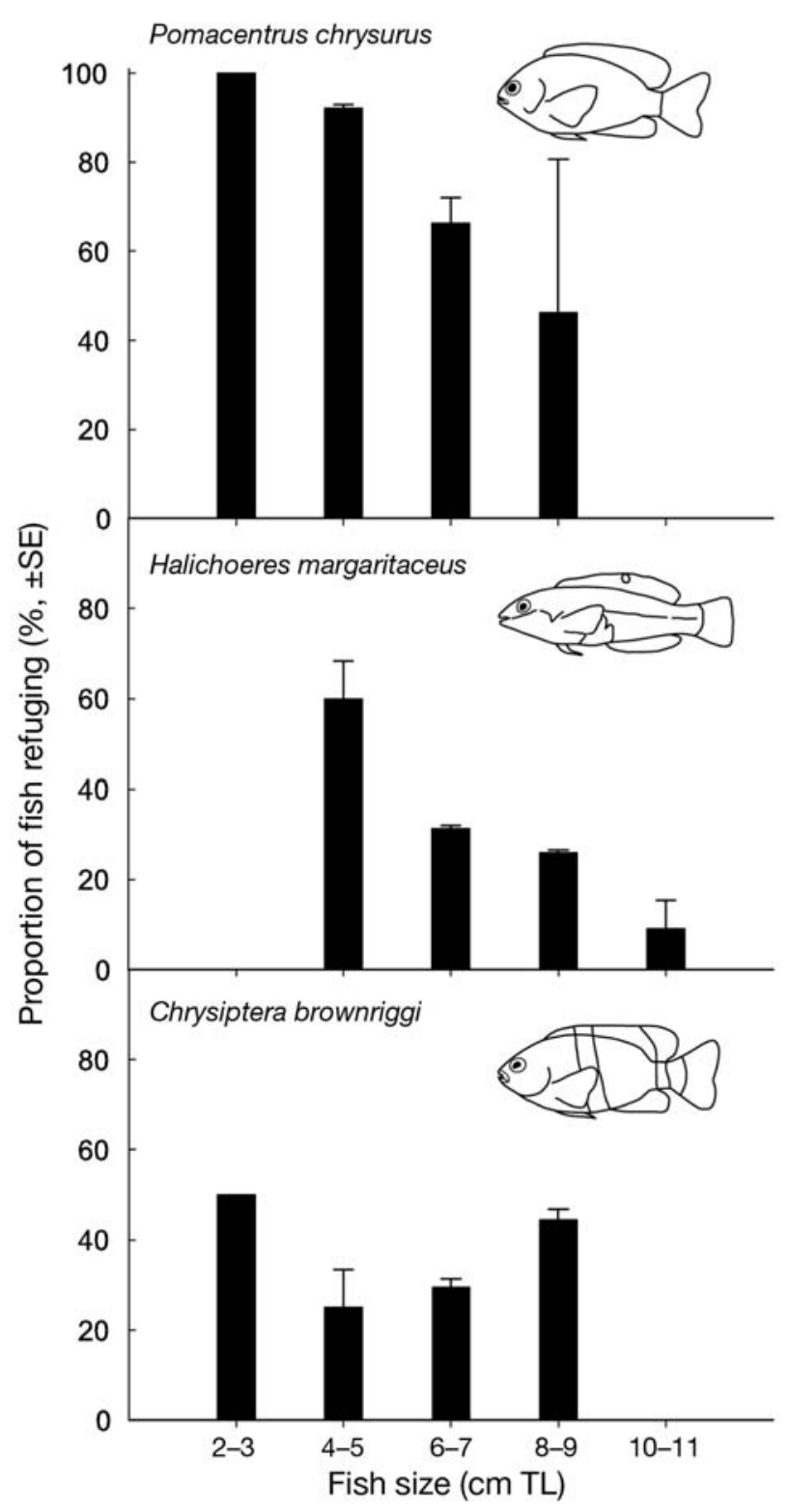

Fig 3. Pomacentrus chrysurus, Halichoeres margaritaceus and Chrysiptera brownriggi. Proportional refuging of individuals in 5 size categories. The $\mathrm{n}$ values for each species from smallest to largest are $P$. chrysurus $(20,38,83,13), H$. margaritaceus $(5,48,50,11)$ and $C$. brownriggi $(4,15,44,8)$

Table 1. Pomacentrus chrysurus, Halichoeres margaritaceus and Chrysiptera brownriggi. Regression analysis of refuging behaviour with size in 3 reef fish species. ${ }^{*} \mathrm{p}<0.05$

\begin{tabular}{|lrcc|}
\hline \multirow{2}{*}{ Species } & \multicolumn{3}{c|}{ (Logit regression) } \\
& \multicolumn{3}{c|}{ Body size versus \% refuging } \\
& Wald-statistic & $\mathrm{n}$ & $\mathrm{p}$ \\
\hline P. chrysurus & 15.27 & 154 & $<0.01^{*}$ \\
H. margaritaceus & 4.55 & 114 & $0.03^{*}$ \\
C. brownriggi & 0.02 & 71 & 0.88 \\
\hline
\end{tabular}


Table 2. Pomacentrus chrysurus, Halichores margaritaceus and Chrysiptera brownriggi. Comparison of the average refuge sizes available in the substratum and the refuge sizes used by the 3 species in the field. Means and SE shown. Significant differences in refuge use from substratum availability are marked $\left({ }^{*} \mathrm{p}<0.05\right)$

\begin{tabular}{|lcccc|}
\hline \multicolumn{3}{c}{ Substratum holes } & \multicolumn{2}{c|}{ Coral heads } \\
& Size $\left(\mathrm{cm}^{3}\right)$ & $\mathrm{n}$ & Size $\left(\mathrm{cm}^{3}\right)$ & $\mathrm{n}$ \\
\hline Available & $1111 \pm 131$ & 205 & $8789 \pm 960$ & 235 \\
substratum refuges & & & & \\
Refuge use by species & & & \\
$\begin{array}{l}\text { P. chrysurus } \\
\text { H. margaritaceus }\end{array}$ & $985 \pm 120$ & 40 & $3722 \pm 677$ & 23 \\
C. brownriggi & $2585 \pm 975^{*}$ & 12 & $2150 \pm 478^{*}$ & 18 \\
& & & & \\
\hline
\end{tabular}

\section{DISCUSSION}

Most studies of refuging behaviour in fishes have focused on predator avoidance (e.g. Beukers \& Jones 1998, Sale 2002, Lehtiniemi 2005). In contrast, our study emphasises the potential direct biophysical advantages of substratum refuge use by decreasing locomotor demand while exposed to a strong ambient current. Pomacentrus chrysurus, Halichoeres margaritacues and Chrysiptera brownriggi all used specific substratum refuge types in the field, with more than $50 \%$ of observed individuals positioning themselves within microhabitat structures that provided significant shelter from ambient flows. While each species positively selected different refuge types, coral heads and substratum holes were the 2 most frequently used refuges in terms of overall number of refuging individuals. Notably, both experimental and field measures revealed that these 2 refuge types reduced ambient flows by 60 to $100 \%$, depending on ambient flow speed and refuge dimensions. The degree of refuging displayed by these reef fishes also appears to be strongly linked to their relative swimming abilities. Slower-swimming species tended to refuge more frequently and occupy a lower part of the water column (presumably to exploit boundary layer effects, Fulton et al. 2001) than individuals of stronger swimming abilities, with $72 \%$ refuging in adult $P$. chrysurus $\left(U_{\mathrm{pc}}=26.7 \mathrm{~cm} \mathrm{~s}^{-1}\right.$, Fulton 2007$)$, versus $32 \%$ refuging in adult $C$. brownriggi $\left(U_{\mathrm{pc}}=35.2 \mathrm{~cm} \mathrm{~s}^{-1}\right.$, Fulton 2007) of the same length. Interestingly, even with growth to adult size, many of these fishes continued to use refuges extensively, which runs contrary to the theory that such refuging behaviour is largely linked to predation risk at a small size (Sale 2002).

Refuging is a common behavioural trait in many fishes, especially on wave-swept coral reef flats (Bellwood \& Wainwright 2001, Fulton et al. 2001, Fulton \& Bellwood 2002a), where this behaviour may be driven by avoidance of extreme flow levels. A recent experimental study found that Pomacentrus chrysurus and Halichoeres margaritaceus do not possess the swimming abilities necessary to overcome the average $60 \mathrm{~cm} \mathrm{~s}^{-1}$ flow conditions found on the reef flats for more than a few minutes at a time (Johansen et al. 2007). However, with access to refuge holes, these same fishes were able to remain in a $60 \mathrm{~cm} \mathrm{~s}^{-1}$ flow habitat for several days without fatigue (Johansen et al. 2007) with some indication that each species increased its refuge use with increasing flow speed (J. Johansen pers. obs.). Our study confirms that these species preferentially select and extensively use the same specific refuge types in the field, and that the refuges confer significant flow reductions, providing strong evidence in support of flow refuging as a significant determinant of patterns of habitat use in these coral reef fishes. Ultimately, it appears that $P$. chrysurus and $H$. margaritaceus have gained access to the reef flat and its resources through a well-developed refuging behaviour, rather than an enhanced swimming capacity befitting the ambient high-flow characteristics of this habitat.

Although all 3 study species demonstrated welldeveloped refuging behaviour in the field, their refuge selectivity patterns differed considerably from refuge availability and each other. Such differences in refuge preference may be linked to differences in feeding mode, swimming ability and competitive interactions between species. For example, Pomacentrus chrysurus is an opportunistic plankton and benthic algal feeder (Allen 1991), which can acquire its food by short duration excursions into the ambient flow. In contrast, Halichoeres margaritaceus feeds on benthic invertebrates and may have to search widely for its dispersed and elusive prey (Fulton \& Bellwood 2002b). As such, H. margaritaceus and other benthic invertebrate feeders may be disadvantaged by residing in one small area adjacent to a substratum hole. This is consistent with the observed patterns of refuge use, with $P$. chrysurus refuging and using substratum holes twice as often as $H$. margaritaceus (which mainly used coral head refuges), as well as the ranking of swimming abilities for the 3 species (H. margaritaceus $>$ Chrysiptera brownriggi $>$ P. chrysurus; Fulton 2007). Although no inter-specific antagonistic interactions were observed, it is likely that the pomacentrids, at least, may have been aggressively defending refuges. Both $C$. brownriggi and P. chrysurus are highly territorial toward a range of species (Allen 1991), providing a possible explanation for interspecific differences in the types of refuges and sizes of refuge holes used and why some potential refuges remained unused (if they were within the territory of a dominant individual). 
Differences in refuge preferences may also be linked to the flow attributes around each refuge type and the relative exposure to predation. While substratum holes are generally thought to be most effective at providing flow reduction as well as shelter from large predators (Hixon \& Beets 1993, Sale 2002), their occupation may be limited by the size of the refuging individual. In contrast, the more exposed coral head refuge appears to provide a similar level of flow reduction (both experimentally and in the field), but may leave individuals visible to predators. However, once detected by predators, the greater freedom of movement around such a refuge, which is open to all sides, may also provide fishes with a greater chance of escape. This would suggest that fishes using a more open refuge type may need to exhibit a greater swimming ability to combat flow and escape predators, and indeed, the species that positively selected coral heads, Halichoeres margaritaceus, is the fastest-swimming species in the group. In addition, with smaller and slower fishes often being more vulnerable to predators (Sale 2002), and refuging more frequently than larger and faster individuals, predator avoidance cannot be discounted. Thus, while flow avoidance appears likely as a significant driver of refuging behaviour, predator avoidance may also be a significant contributing factor, with the differences between species in refuging behaviour and water column use reflecting their different swimming abilities and risk of predation.

Regardless of the extent and type of refuge use, flow reduction provided by substratum holes and coral heads appears to provide a significant biophysical advantage to fishes. Following Alexander (2005), the relative energy requirements for fish swimming can be estimated in both laminar (energy $[E]=$ [body mass $\left.(\mathrm{g})]^{0.5} \times\left[\operatorname{speed}\left(\mathrm{cm} \mathrm{s}^{-1}\right)\right]^{2.5}\right)$ and turbulent flow $([E]=$ $\left.[\text { body mass }(\mathrm{g})]^{0.6} \times\left[\text { speed }\left(\mathrm{cm} \mathrm{s}^{-1}\right)\right]^{2.8}\right)$. Based on these formulae, fishes in a $60 \mathrm{~cm} \mathrm{~s}^{-1}$ ambient flow would reduce energy consumption from swimming by approximately 71 to $95 \%$ when using either a substratum hole or coral head refuge (cf. Fig. 2). Although we used unidirectional flows to examine flow patterns within each refuge type, it is apparent from field measurements that refuges do indeed reduce flow velocities significantly and, if well exploited, may yield considerable energetic savings (Liao et al. 2003). Consequently, such energy savings from flow refuging provide a clear rationale for the refuging and swimming patterns observed in the field. In addition, the swimming activity and water column use of each species was consistent with their feeding mode and swimming ability (i.e. energy uptake and expenditure). Specifically, Halichoeres margaritaceus (foraging on the substratum) stayed closer to the substratum than both Pomacentrus chrysurus and Chrysiptera brownriggi (feed- ing on plankton), with the bigger and stronger-swimming $C$. brownriggi foraging farthest away from the substratum.

Overall, this study demonstrates that fishes inhabiting wave-swept coral reef flats exhibit strong individual selection for specific substratum refuges and that the use of these refuges seems to depend on swimming ability and foraging behaviour. Such flow refuging appears to facilitate the successful exploitation of highflow habitats by coral reef fishes with a limited swimming capacity. While our examinations suggest that significant energetic savings may be obtained by such refuging behaviour, more direct assessments of the energetic implications would offer a greater insight into microhabitat use by demersal fishes. Similarly, the relative causal effects of predator or flow-avoidance in shaping these patterns of refuging behaviour could be further examined using a predator presence-absence manipulation across a spectrum of ambient flow speeds. While the possible advantages for predator avoidance are an important aspect of such refuging behaviour, it appears that flow refuging can also have a profound influence on patterns of habitat use in coral reef fishes occupying wave-swept locations.

Acknowledgements. We thank A. Gonzales Cabello, the staff of the James Cook University Research Aquarium and Lizard Island Research Station for their assistance with field and aquarium logistics, and 3 anonymous reviewers for helpful comments on the manuscript. Financial support was provided by the Lizard Island Reef Research Foundation (C.J.F), and the Australian Research Council (D.R.B).

\section{LITERATURE CITED}

Alexander RM (2005) Models and the scaling of energy costs for locomotion. J Exp Biol 208:1645-1652

Allen GR (1991). Damselfishes of the world. Mergus Publishers, Melle

Asaeda T, Vu TK, Manatunge J (2005) Effects of flow velocity on feeding behaviour and microhabitat selection of the stone moroko Pseudorasbora parva: a trade-off between feeding and swimming costs. Trans Am Fish Soc 134: $537-547$

Bell WH, Terhune LDB (1970) Water tunnel design for fisheries research. Fish Res Board Can 195:1-69

Bellwood DR, Wainwright PC (2001) Locomotion in labrid fishes: implications for habitat use and cross-shelf biogeography on the Great Barrier Reef. Coral Reefs 20:139-150

Beukers JS, Jones GP (1998) Habitat complexity modifies the impact of piscivores on a coral reef population. Oecologia 114:50-59

Chesson J (1983) The estimation and analysis of preference and its relationship to foraging models. Ecology 64: $1297-1304$

Fulton CJ (2007) Swimming speed performance in coral reef fishes: field validations reveal distinct functional groups. Coral Reefs 26:217-228

Fulton CJ, Bellwood DR (2002a) Ontogenetic habitat use in labrid fishes: an ecomorphological perspective. Mar Ecol Prog Ser 236:255-262 
Fulton CJ, Bellwood DR (2002b) Patterns of foraging in labrid fishes. Mar Ecol Prog Ser 226:135-142

Fulton CJ, Bellwood DR (2005) Wave-induced water motion and the functional implications for coral reef fish assemblages. Limnol Oceanogr 50:255-264

Fulton CJ, Bellwood DR, Wainwright PC (2001) The relationship between swimming ability and habitat use in wrasses (Labridae). Mar Biol 139:25-33

Gerstner CL, Webb PW (1998) The station-holding performance of the plaice Pleuronectes platessa on artificial substratum ripples. Can J Zool 76:260-268

Hixon MA, Beets JP (1993) Predation, prey refuges, and the structure of coral-reef fish assemblages. Ecol Monogr 63: 77-101

Johansen JL, Fulton CJ, Bellwood DR (2007) Avoiding the flow: refuges expend the swimming potential of coral reef

Editorial responsibility: Matthias Seaman, Oldendorf/Luhe, Germany fishes. Coral Reefs 26:577-583

> Lehtiniemi M (2005) Swim or hide: Predator cues cause species specific reactions in young fish larvae. J Fish Biol 66: 1285-1299

Liao JC, Beal DN, Lauder GV, Triantafyllou MS (2003) Fish exploiting vortices decrease muscle activity. Science 302: $1566-1569$

Sale PF (2002). Coral reef fishes: dynamics and diversity in a complex ecosystem. Academic Press, London

Vogel S, LaBarbera M (1978) Simple flow tanks for research and teaching. Bioscience 28:638-643

Webb PW (1998) Entrainment by river chub and smallmouth bass on cylinders. J Exp Biol 201:2403-2412

Williams DM (1991). Patterns and processes in the distribution of coral reef fishes. In: Sale PF (ed) The ecology of fishes on coral reefs. Academic Press, London, p 437-474

Submitted: August 16, 2007; Accepted: March 14, 2008

Proofs received from author(s): May 8, 2008 